\section{Canada's NASA}

CANADA finally has a space agency. After months of squabbling over where it should be located, the government announced earlier this month that the new agency's headquarters would be in the greater Montreal area. Until now, responsibility for Canada's space activities fell to many ministries. The decision to base the new agency in the province of Quebec ends a political battle between predominantly French-speaking Quebec and the predominantly English-speaking Ontario that held up plans to establish the agency. In addition to coordinating Canadian activities on the space station, the agency will manage RADARSAT, a planned Earth remotesensing satellite, MSAT, an advanced communications satellite, and the Canadian astronaut office. The current fiscal year's space budget is $C \$ 120$ million, rising to $\mathrm{C} \$ 150$ million next year.

Larkin Kerwin has resigned as president of the Canadian National Research Council to become president-designate of the new agency.

J.P.

\section{President removed}

DR Pulat Khabibullaev, nuclear physicist and former president of the Uzbek Academy of Sciences, has been replaced as president of the Uzbek Republic on the grounds of corruption. He was accused of having "actively assisted" the scientific careers of close relatives of now-disgraced local party leaders, procuring them posts for which they were insufficiently qualified and which they treated as virtual sinecures. Furthermore, he is said to have used his position as vice-president and then president of the academy to have his name attached as coauthor to no fewer than 322 scientific papers to which he had contributed nothing. Called to account before the bureau of the Central Committee of the Communist Party of Uzbekistan, Khabibullaev made a formal self-criticism, whereupon the Party recommended that he be allowed to resign as president of Uzbekistan and "transferred to scientific work".

V.R.

\section{Fang speaks out}

DR Fang Lizhi, the Chinese astrophysicist and dissident who was prevented by the police from attending US President George Bush's banquet in Beijing, has not let the incident pass unchallenged. At a press conference at his home the following day, he suggested that the reluctance of the Chinese leadership to have dinner with one dissident on one single occasion must surely raise doubts about their "promised tolerance" of the future presence of nonsocialist Hong Kong in post-1997 China. Official Chinese spokespersons continue to attack the original invitation as "disrespectful" to the president's official hosts the Chinese leaders - and US reaction to Fang's exclusion as "irresponsible". V.R.

\title{
Outside influences resented
}

\section{São Paulo}

SoutH American government officials promised at a series of meetings last week to respect the rain-forest environment while promoting development, and called for more research on the damage to rain forests. But a concurrent scientific meeting on rain-forest ecology dismissed these promises as mere rhetoric, and complained that researchers are being denied resources.

The foreign ministers of Ecuador, Brazil, Colombia, Venezuela, Peru, Surinam, Guiana and Bolivia gathered in Quito, Ecuador, last week for the third meeting of the Amazonian Cooperation Treaty, signed in 1978 to defend the region's environment. The ministers favour "rational" use of Amazonian resources, and condemn "any foreign interference on the policies and actions that the Amazonian countries make in the region".

The governors of several Brazilian states were in Manaus to discuss the newest federal environmental protection programme called "Nossa Natureza" ("Our Nature"). Announced last year as a response to growing internal and international criticism of rain-forest devastation, the programme consists of legislation strengthening forestry and mining codes and creating new protected areas. Brazilian President Jose Sarney is due to sign these measures on 6 April.

But scientists from INPA - Instituto Nacional de Pesquisas da Amazonia (National Institute of Amazon Research) - think otherwise. They feel left out of the planning of "Our Nature" and fear that it is going to be just another meaningless declaration of good intentions. Researchers from the institute held a lastminute "alternative" meeting on 7 and 8 March in Manaus to draft a response to the "Our Nature" approach, but were prevented from presenting their conclusions to the governors meeting nearby.

Brazilian Minister for Industrial Development, Science and Technology, Roberto Cardoso Alves, said in February that the rain forest is "practically intact", with just 1 per cent destroyed. Estimates from INPA put the figure at 8 per cent .

If governments are resisting foreign intervention, the same cannot be said for researchers. INPA has many foreign scientists, mainly US and German. One US scientist, Philip M. Fearnside, has become the institute's media star, by his constant advocacy of preservationist measures. He complains that red tape is drawing away many researchers from the Brazilian side of Amazonia: there are stories that some foreign scientists have had to wait a year for a visa to visit Brazil.

INPA researcher Muriel Saragoussi says the institute may lose more than a third of its 284 researchers if a government decision to dismiss all public servants with less than five years on the job takes effect. The proposed layoffs are a result of a January economic plan by the federal government to try to stave off hyperinflation. Another consequence of this plan is a reduction of 50 per cent in the financing of research institutes.

Research on rain forests will certainly be an important part of the planned International Geosphere-Biosphere Programme (IGBP). The programme's executive director, Thomas Rosswall, toured last week through several Latin American countries to promote the programme. He diplomatically stated in São Paulo that Brazil has sovereignty to decide what to do with its natural resources, but added that all countries will have to take responsibility for what happens to the world's climate. He compared the situation of the rain forest with the emission of sulphur dioxide by Britain; only when scientists showed that British emissions were polluting Europe did the British government take measures to curb them. Brazil may face similar pressure when the true importance of the rain forest to global climate change is conclusively shown. IGBP is likely to place one of its proposed global observatories in the Latin American rain forest. Ricardo Bonalume Neto

\section{Mercurial approach}

São Paulo

THE Brazilian government has been somewhat mercurial in its approach to science and science policy. Two months after deciding to abolish the Ministry for Science and Technology, it announced last week that it was creating a new, cabinetlevel Special Secretary for Science and Technology. The two-month-old Ministry of Industrial Development, Science and Technology, which emerged in the wake of the departure of the four-year-old science ministry, now becomes the Ministry for the Development of Industry and Commerce.

Critics say this confusion of names and ministries underlines the lack of a coherent policy for Brazil's scientific development. Nevertheless, the Brazilian Society for the Advancement of Science praised the creation of the new secretaryship. The society lobbied intensely to recreate the ministry in order to have a single entity to coordinate science policy.

Financial problems for science persist. Some ministry institutes now in the new secretary have less than half the money they need to function. Researchers at the National Institute of Amazon Research (INPA) have to buy fuel for their jeeps out of their own pockets. Ricardo Bonalume Neto 